\title{
Empirical relationships between aerosol mass concentrations and Ångström parameter
}

\author{
J. Kusmierczyk-Michulec, ${ }^{1}$ G. de Leeuw, and C. Robles Gonzalez \\ TNO Physics and Electronics Laboratory, The Hague, The Netherlands
}

Received 25 September 2001; revised 21 January 2002; accepted 28 January 2002; published 12 April 2002.

[1] Empirical relations between aerosol mass concentrations and Angström parameters $\alpha$ were derived from simultaneous optical and chemical measurements on the Baltic in March 1998. The relations apply to mass concentrations of sea salt aerosol (SSA), black carbon (BC) and organic carbon (OC), expressed in terms of their ratio to the total particulate matter (TPM). Using these relations to calculate the mass concentrations of these aerosol components for a different season or a different area, yields favorable results. The relations were obtained and verified for Ångström parameters $0.2 \leq \alpha \leq 1.43$. INDEX TERMS: 0305 Atmospheric Composition and Structure: Aerosols and particles (0345, 4801); 1640 Global Change: Remote sensing; 0365 Atmospheric Composition and Structure: Tropospherecomposition and chemistry

\section{Introduction}

[2] The aerosol optical thickness $\tau_{\mathrm{A}}$ describes the attenuation of radiation in the atmosphere, integrated from the Earth surface to the top of the atmosphere. The Angström parameter $\alpha$ describes the variation of $\tau_{\mathrm{A}}$ with the wavelength $\lambda$

$$
\tau_{\mathrm{A}}\left(\lambda_{1}\right) / \tau_{\mathrm{A}}\left(\lambda_{2}\right)=\left(\lambda_{1} / \lambda_{2}\right)^{-\alpha}
$$

and is related to the aerosol size distribution [Junge, 1963].

[3] In view of the dependence of the aerosol optical properties on the size distribution and the chemical composition, and the chemical speciation as function of particle size, a relation may be expected between the Angström parameter and the chemical composition, cf. Kusmierczyk-Michulec et al. [1999, 2000, 2001]. For instance, Reid et al. [1999] showed that the Angström parameter for smoke particles in Brazil is well correlated with their size, single-scattering albedo and the backscatter ratio. The objective of this paper is to further investigate relations between the Angström parameter and the contribution of different chemical components to the total aerosol mass (TPM).

[4] The analysis is based on simultaneous measurements of $\tau_{\mathrm{A}}$ and aerosol chemical composition undertaken at the Baltic in March 1998. The results are tested versus an independent data set obtained at the Baltic in July 1997. Additional tests were made using data obtained over the Atlantic Ocean during ACE-2 (e.g., Raes et al. [2000]) and from Quinn et al. [2001].

\section{Experimental Data}

[5] Aerosol optical thickness and aerosol chemical composition were measured during cruises at the Baltic Sea, in March 1998 and July 1997 aboard two research vessels: r/v Alexander von Hum-

\footnotetext{
${ }^{1}$ On leave from Institute of Oceanology, Polish Academy of Sciences, Sopot, Poland.
}

boldt and r/v Professor Albrecht Penck (from the Institute for Baltic Sea Research, Warnemuende). The measurements and data analysis procedures were extensively described in KusmierczykMichulec et al. [2001].

[6] Relevant for this paper are the measurements of $\tau_{\mathrm{A}}$ and the aerosol chemical composition. The aerosol optical thickness in eight spectral channels $(412,443,490,510,555,670,765$ and 865 $\mathrm{nm}$, bandwidth $10 \mathrm{~nm}$ ) was measured with a shadow-band spectrophotometer [Olszewski et al., 1995]. The systematic error in $\tau_{\mathrm{A}}$ is less than 0.02 [Rozwadowska and Kusmierczyk-Michulec, 1998].

[7] Chemical composition was determined on filter (cut off diameter $2 \mu \mathrm{m}$ ) and impactor (8 stages, $0.06-16 \mu \mathrm{m}$ diameter) samples as described in detail in Kusmierczyk-Michulec et al. [2001]. Carbonaceous particles (black carbon (BC) and organic carbon (OC)) and total particulate matter (TPM) were analysed in parallel on filters with two independent sampling lines [see also Rullean, 2000]. The sodium concentration $(\mathrm{Na})$ in impactor samples was determined by flame atomic emission spectroscopy (F-AES) [see also Plate, 2000].

\section{Empirical Relations Between Aerosol Composition and the Ångström Parameters}

[8] Aerosol optical thickness measurements can only be made in cloud free conditions, during daytime, and are instantaneous snap shots of the column integrated atmospheric condition. The sunphotometer measurements were repeated every 15 minutes. In contrast, sampling of sufficient aerosol mass for reliable chemical analysis usually takes on the order of half a day, and hence the results will present averages over a relatively long time. For comparison of these two types of measurements, Angström parameters calculated from eq. (1) were averaged over the impactor sampling period. In the analysis, only data were included for which both averaged optical data and the chemical samples, including both TPM and other aerosol components (Na, BC and OC), were available. With these restrictions, 12 data points remained from the March 1998 cruise and 3 for July 1997. The values of $\tau_{A}$ were up to 0.6 at $555 \mathrm{~nm}$ and TPM varied between $4.4 \mu \mathrm{g} \mathrm{m}^{-3}$ and $38 \mu \mathrm{g}$ $\mathrm{m}^{-3}$, in conditions varying from clean marine to polluted (see Kusmierczyk-Michulec et al. [2001] for details).

[9] Initially, only the March 1998 data were used to derive empirical relations between aerosol components and Ångström parameters. The aerosol components are expressed as the ratio of each component to the total particular matter, i.e. X/TPM, where $\mathrm{X}=$ $\mathrm{Na}, \mathrm{OC}$ or $\mathrm{BC}$.

[10] A scatter plot of Na/TPM versus $\alpha$ is shown in Figure 1. The standard deviation of $\alpha$, determined from the data for each sampling period, is in the range of 5\%-30\% (see horizontal error bars in Figure 1). The vertical error bars result from the uncertainty in the measurements of both $\mathrm{Na}$ (detection limits of $0.8 \mathrm{nmol} / \mathrm{m}^{3}$ ) and TPM (an absolute accuracy of $10 \mu \mathrm{g}$ ). A power law fit to the data yields the relation (correlation coefficient $r=0.91$ ):

$$
\frac{N a}{T P M}=(8.6 \pm 3.3) \times 10^{-3} \alpha^{(-1.525 \pm 0.315)}
$$




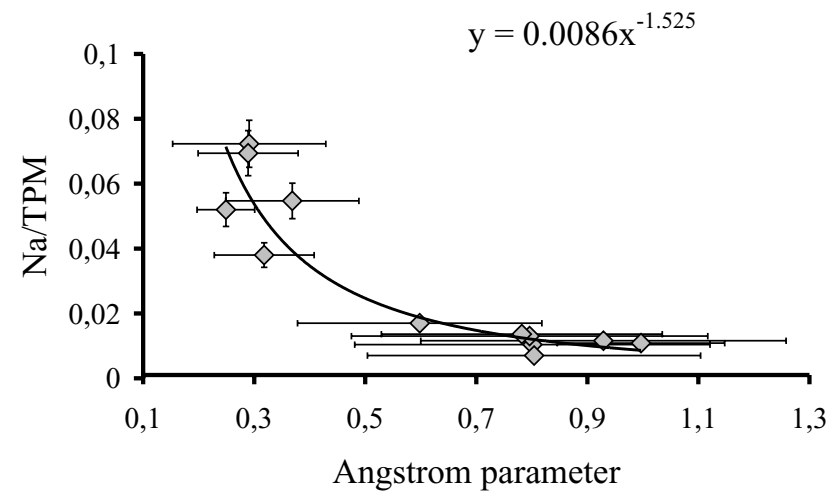

Figure 1. Relation between the ratio of sodium mass concentration and total particular matter (Na/TPM), and the mean values of the Angström parameters determined during each sodium measurement. Min/max values of the Ångström parameters (mean value \pm std), marked by horizontal bars, indicate the daily variation.

[11] Note that the uncertainties in the regression coefficients are given for the $95 \%$ confidence level. This relation applies to $\alpha \geq$ 0.2 , i.e. the minimum value of $\alpha$ available in the data set. If instead of $N a$ the total sea salt aerosol (SSA) mass concentration is required, eq. (2) can be converted using $S S A\left[\mu \mathrm{g} / \mathrm{m}^{3}\right]=3.257 \times$ $\mathrm{Na}^{+}\left[\mu \mathrm{g} / \mathrm{m}^{3}\right]$ :

$$
\frac{S S A}{T P M}=(2.8 \pm 1.1) \times 10^{-2} \alpha^{(-1.525 \pm 0.315)},
$$

[12] Similarly, relations can be derived between the ratios of OC or BC to TPM, and $\alpha$. The results are:

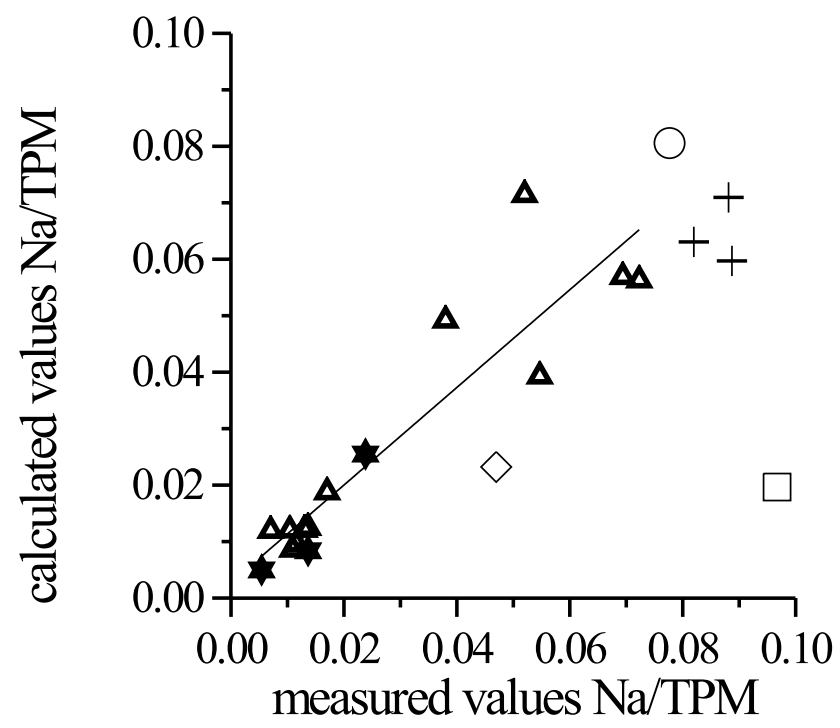

Figure 2. Values of $\mathrm{Na} / \mathrm{TPM}$ calculated on the basis of the Angström parameters versus experimental data. Triangles correspond to data collected in March 1998, stars to data collected in July 1997, the line is a least squares fit to these data (eq. (2)). Also included are data derived from Quinn et al. [2001] and Voss et al. [2001]. Crosses represent data obtained in the regions of North and South Atlantic marine air masses, the open circle, diamond and square-data obtained in the presence of the African dust, the mixed African dust and biomass burning, and biomass burning, respectively.

$$
\frac{O C}{T P M}=(4.17 \pm 0.42) \times 10^{-1} \alpha^{(0.998 \pm 0.245)}, \quad(\mathrm{r}=0.88)
$$

and

$$
\frac{B C}{T P M}=(2.43 \pm 0.56) \times 10^{-2} e^{(1.262 \pm 0.265) \alpha}, \quad(r=0.84)
$$

[13] The relative error $\varepsilon$ of the empirical formulas (2)-(4) was estimated using the relation $\varepsilon=\left(\mathrm{k}_{\text {cal }}-\mathrm{k}_{\text {meas }}\right) / \mathrm{k}_{\text {meas }}$, where $\mathrm{k}=\mathrm{Na} / \mathrm{TPM}, \mathrm{BC} / \mathrm{TPM}$ and OC/TPM, the subscript cal indicates that $k$ was determined from eqs. (2)-(4), and the subscript meas refers to the experimental values. For the data of March 1998, the mean $\varepsilon$ for eqs. (2)-(4) was between $3-4 \%$ and the standard deviation in the relative error $\sigma_{\varepsilon}$ did not exceed $30 \%$. Application of eqs. (2)-(4) to the July 1997 data shows that they also hold for the few data available in the summer season. The mean $\varepsilon$ was smaller than $15 \%$ and $\sigma_{\varepsilon}$ smaller than $23 \%$. In view of this good agreement, both data sets were combined, yielding mean values of $\varepsilon$ between $0.2 \%$ and $5 \%$, and $\sigma_{\varepsilon}$ between $24 \%$ and $29 \%$. Figure 2 shows a scatter plot of the calculated versus the measured $\mathrm{Na}$ /TPM for both data sets.

[14] The variation of the aerosol composition with the Angström parameter is presented in Figure 3. The contributions of SSA, OC and BC to TPM were computed using the empirical relations (3), (4a), and (4b). Obviously, also other aerosol types, such as water-soluble (e.g. ammonium sulphate and ammonium nitrate), dust and biological particles, may contribute to the TPM. For simplicity, the group of aerosols different from SSA, OC and $\mathrm{BC}$ is defined here as the "residue".

[15] Identification of all aerosols, which are included in the "residue", would be difficult. For the Baltic Sea, the major contribution to the "residue" comes from ammonium sulphates and a relatively small amount of ammonium nitrate, especially for $0.56<\alpha \leq 0.97$ [Kusmierczyk-Michulec et al., 2001]. For $\alpha=0.97$ all residue particles were ammonium salts; the aerosol mass was composed of: $2.9 \%$ SSA, $40.4 \%$ OC, $8.3 \%$ BC and $48.4 \%$ ammonium salts. In other cases the residue may also contain aerosol types such as dust or biomass aerosol. Dust is often observed in the maritime atmosphere, for example over the northeastern tropical Atlantic (e.g., Chiapello et al. [1999]), or over the

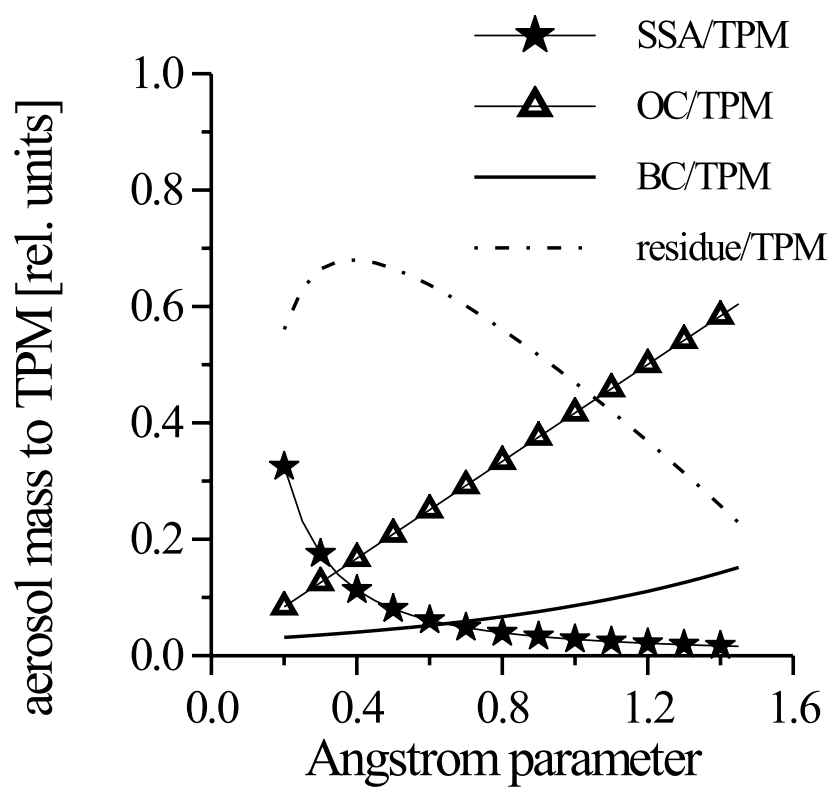

Figure 3. Relative contributions of individual aerosol components to TPM as a function of Angström parameter, using the empirical relations: (3), (4a) and (4b). 


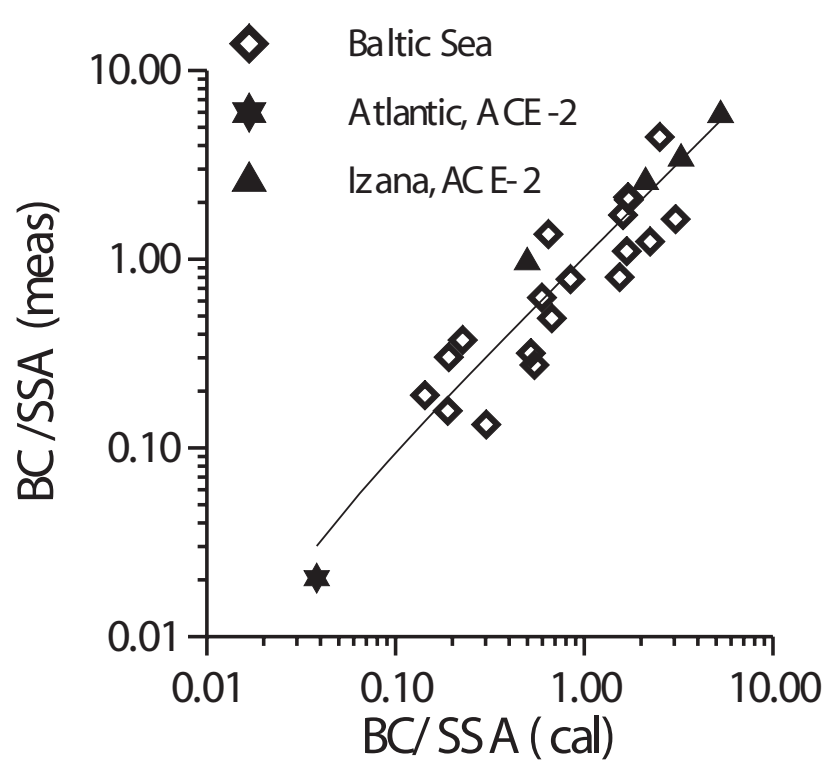

Figure 4. BC/SSA (meas), calculated from measurements, versus values $\mathrm{BC} / \mathrm{SSA}(\mathrm{cal})$, computed from measured Ångström parameters using eqs. (3) and (4b). Diamonds refer to data collected in March 1998 and July 1997 on the Baltic Sea. The star indicates data collected on the Atlantic Ocean during ACE-2, for which the Ångström parameter was retrieved from ATSR-2 data. Triangles correspond to data collected at the Izaña observatory (see text for further explanation).

North Sea (e.g., Ebert et al. [2000]), but their concentration will depend on the meteorological situation and the presence of sources upwind.

\section{Discussion}

[16] The results presented in section 3 show that empirical relations (2)-(4) apply over the Baltic, in two different seasons (winter and summer). Weather conditions were described in detail in Kusmierczyk-Michulec et al. [2001].

[17] Generally, comparison between total column integrated values and "surface" values is possible only for the well-mixed atmospheric boundary layer. Apparently, in view of the good agreement between measured and calculated values for the data available, in this case $\tau_{\mathrm{A}}$ over the Baltic is representative for the surface aerosol properties.

[18] The next question was whether the obtained relations could also be applied to another region. A literature search for $\tau_{\mathrm{A}}$ data in combination with simultaneous measurements of aerosol composition led to the ACE-2 experiment conducted over the Atlantic Ocean in July 1997 (cf. Raes et al. [2000]). BC and $\mathrm{Na}$ data, collected at the Izaña observatory $\left(28.30^{\circ} \mathrm{N}, 16.50^{\circ} \mathrm{W}\right)$ were published by Putaud et al. [2000]. Unfortunately no TPM data were available, therefore eqs. (2)-(4) were evaluated using $\mathrm{BC} / \mathrm{SSA}$ as a function of $\alpha$. Collocated sunphotometer data for 30 June, 1, 8 and 14 July were obtained from Smirnov et al. [1998]. The published Angström parameters are coincident with the chemical measurements. In addition, data collected on 12 July on the research vessel Vodyanitskiy were used: black carbon [Novakov et al., 2000] and sodium [Johnson et al., 2000]. The Angström parameter for this day was determined from ATSR-2 data, using the single view algorithm described by Veefkind and De Leeuw [1998a]. To complete the number of experimental data for this test, also measurements from the Baltic Sea in July 1997 for which TPM was not available, were added to the database. In total the number of data points $\mathrm{N}$ used in the test thus increased from 15 to 25 . BC/SSA(meas), calculated from measurements, and
BC/SSA(cal), computed from the Angström parameter using eqs. (3) and (4b) (see Figure 4), are in a good agreement ( $\mathrm{r}=0.9, \varepsilon=$ $18 \%$ and $\sigma_{\varepsilon}=54 \%, \mathrm{~N}=25$ ). Similarly, data from Quinn et al. [2001] and Voss et al. [2001] obtained during a cruise from Norfolk (Virginia) to Cape Town (South Africa) in January/ February 1999 were used to test the relations found for sodium (eq. (2)). The results, included in Figure 2, show that eq. (2) applies also for this data set except in the case where biomass aerosols are present.

[19] These empirical relations can be useful to obtain information on the spatial distribution of the aerosol composition using satellite data. As a test, the relative $\mathrm{BC}$ concentrations over an area in Western Europe were calculated from $\tau_{\mathrm{A}}$ fields retrieved for 12 August 2000 from ATSR-2 data, using the dual view algorithm described by Veefkind et al. [1998b]. Application of eq. (4b) resulted in the BC/TPM ratios, which were compared with ground observations available for two Belgium cities. Values of BC/TPM for Ghent and Waasmunster, based on satellite retrieval, are $18 \%$ and $16 \%$, respectively, as compared to in-situ measurements in the urban site in Ghent (19\%) and the rural site in Waasmunster (14\%) [Maenhaut and Cafmeyer, 1998]. These results indicate that empirical relations such as derived here could also be valuable to obtain information on the aerosol chemical composition over land. However, more measurements are required, in particular including aerosol components other than those indicated above.

\section{Conclusions}

[20] The presented analysis shows a strong and consistent relationship between aerosol quantities that can be measured from satellites and the aerosol chemical composition. Results are complementary to relations between Ångström parameters and physical properties [Reid et al., 1999]. The current parameterisations apply to the regions for which they were derived and obviously need to be evaluated for other areas. Although the application of the derived formulas does not give the complete aerosol composition, only the contributions of the specified components, the results indicate the potential of such equations. Further research is required to develop similar equations for other major components such as sulphate, nitrate, dust, bio mass particles, volcanic ash, etc.

[21] Acknowledgments. The work described in this paper was supported by the Netherlands Space Research Organization (SRON), contract EO-037. The authors thank Helene Cachier and Stephane Rullean from LSCE, CEA/CNRS for BC, OC and TPM data, and Michael Schulz and Elke Plate from the University of Hamburg for providing sodium data. The data were collected during the BASYS Atmospheric Load Experiments supported by the European Community, under EU contracts MAS3-CT960058 and IC96-0080 (BASYS/INCO). The ATSR-2 data were kindly provided by the European Space Agency (ESA-ESRIN).

\section{References}

Chiapello, I., G. Bergametti, B. Chatenet, F. Dulac, I. Jankowiak, C. Liousse, and E. Santos Soares, Contribution of the different aerosol species to the aerosol mass load and optical depth over the northeastern tropical Atlantic, J. Geophys. Res., 104, 4025-4035, 1999.

Ebert, M., S. Weinbruch, P. Hoffmann, and H. M. Ortner, Chemical characterization of North Sea aerosol Particles, J. Aerosol Sci., 31(5), $613-632,2000$

Johnson, D. W., S. Osborne, R. Wood, K. Suhre, P. K. Quinn, T. Bates, M. O. Andreae, K. J. Noone, P. Glantz, B. Bandy, J. Rudolph, and C. O'Dowd, Observations of the evolution of the aerosol, cloud and boundary-layer characteristics during the 1st ACE-2 Lagrangian experiment, Tellus, 52B, 348-374, 2000.

Junge, C. E., Air Chemistry and Radioactivity, 382 pp., Academic, San Diego, Calif., 1963.

Kusmierczyk-Michulec, J., O. Krueger, and R. Marks, Aerosol influence on the sea-viewing wide-field-of-view sensor bands: Extinction measurements in a marine summer atmosphere over the Baltic Sea, J. Geophys. Res, 104(D12), 14,293-14,307, 1999.

Kusmierczyk-Michulec, J., and R. Marks, The influence of sea-salt 
aerosols on the atmospheric extinction over the Baltic and the North Seas, J. Aerosol. Sci., 31, 1299-1316, 2000.

Kusmierczyk-Michulec, J., M. Schulz, S. Ruellan, O. Krueger, E. Plate, R. Marks, G. de Leeuw, and H. Cachier, Aerosol composition and related optical properties in the marine boundary layer over the Baltic Sea, J. Aerosol Sci., 32(8), pp. 933-955, 2001.

Maenhaut, W., and J. Cafmeyer, Long-term atmospheric aerosol study at urban and rural sites in Belgium using multi-elemental analysis by particle-induced X-ray emission spectrometry and short-irradiation instrumental neutron activation analysis, X-Ray Spectrometry, 27, 236-246, 1998.

Novakov, T., T. S. Bates, and P. K. Quinn, Shipboard measurements of concentrations and properties of carbonaceous aerosols during ACE-2, Tellus, 52B, 228-238, 2000

Olszewski, J., J. Kusmierczyk-Michulec, and M. Sokólski, The method of continuous measurement of the diffusivity of the natural light field, Oceanologia, 37(2), 299-310, 1995.

Plate, E., Variabilität der Zusammensetzung anorganischer Aerosole insbesondere der reaktiven Stickstoffverbindungen- in küstennahen Gebieten der Nordsee und Ostsee (in German), Ph.D. thesis, Univ. of Hamburg, Germany, 2000 .

Putaud, J. P., R. van Dingenen, M. Mangoni, A. Virkkula, F. Raes, H Maring, J. M. Prospero, E. Swietlicki, O. H. Berg, R. Hillamo, and T. $\mathrm{M} \cdot \mathrm{kel}$., Chemical mass closure and assessment of the origin of the submicron aerosol in the marine boundary layer and the free troposphere at Tenerife during ACE-2, Tellus, 52B, 141-168, 2000

Quinn, P. K., D. J. Coffman, T. S. Bates, T. L. Miller, J. E. Johnson, K. Voss, E. J. Welton, and C. Neusüss, Dominant aerosol chemical components and their contribution to extinction during the Aerosols99 cruise across the Atlantic, J. Geophys. Res., 106, 20,783-20,809, 2001.
Raes, F., T. Bates, F. McGovern, and M. Van Liedekerke, The 2nd Aerosol Characterization Experiment (ACE-2): general overview and main results, Tellus, 52B, 141-168, 2000.

Reid, J. S., T. F. Eck, S. A. Christopher, P. V. Hobbs, and B. Holben, Use of the Ongstrom exponent to estimate the variability of optical and physical properties of aging smoke particles in Brazil, J. Geophys. Res., 104, $27,474-27,489,1999$

Rozwadowska, A., and J. Kusmierczyk-Michulec, Finding the aerosol optical thickness over the Baltic Sea-comparison of two methods, Oceanologia, 40(3), 165-182, 1998.

Rullean, S., Comparative study of carbonaceous aerosol in tropical, urban and arctic atmospheres: specificity of sources and atmospheric evolution (in French), Ph. D. thesis, LSCE, CEA/CNRS, Gif-Sur-Yvette, Cedex, France, 2000

Smirnov, A., B. N. Holben, I. Slutsker, E. J. Welton, and P. Formenti, Optical properties of Saharan dust during ACE 2, J. Geophys. Res., 103, 28,079-28,092, 1998.

Veefkind, J. P., and G. de Leeuw, A New Algorithm to Determine the Spectral Aerosol Optical Depth from Satellite Radiometer Measurements, J. Aerosol Sci., 29, 1237-1248, 1998 a.

Veefkind, J. P., G. de Leeuw, and P. A. Durkee, Retrieval of Aerosol Optical Depth over Land using two-angle view Satellite Radiometry during TARFOX, Geophys. Res. Lett., 25, 3135-3138, 1998 b.

Voss, K. J., E. J. Welton, P. K. Quinn, R. Frouin, M. Miller, and R. M. Reynolds, J. Geophys. Res., 106, 20,811-20,819, 2001.

J. Kusmierzcyk-Michulec, G. de Leeuw, and C. R. Gonzalez, TNO Physics and Electronics Laboratory, P.O. Box 96864, 2509 JG, The Hague, The Netherlands. 